\title{
Experimental Design Of Manganese Stone Minerals On Carbon Steel With Pack Carburizing Approach Using Factorial Methods
}

\author{
Oktovianus Dharma Rerung ${ }^{1}$, Fransiskus Sapar ${ }^{1}$, Roymons Jimmy Dimu ${ }^{1}$ \\ \{dharmarerung@gmail.com, saparf45@gmail.com, roydimu@gmail.com\} \\ Department of Mechanical Engineering, Kupang State Polytechnic ${ }^{1}$
}

\begin{abstract}
The design of the manganese mineral powder experiment on carbon steel began with the desire to see the phenomenon of Ferro $(\mathrm{Fe})$ and manganese $(\mathrm{Mn})$ metal atoms with the help of high-temperature heat. This phenomenon is tried by using a pack carburizing using manganese mineral powder and using an air conditioner for the extraction process. This research also deals with the pyrometallurgical process. The research method used is a true experimental design and factorial experimental methods. After calculating the ANOVA in a factorial experiment, the hardness of the steel can be known because it is influenced by the holding time factor and its interactions, namely the temperature and composition of the coal. The purpose of this study is to produce a hardness value in accordance with the formation of manganese content on the surface of carbon steel. After the Scanning Electron Microscope (SEM) test, it appears that the surface morphological changes in the steel are rougher than the original object and the Energy Dispersive X-ray Spectroscopy (EDX) test forms the composition of the steel alloy on the surface.
\end{abstract}

Keywords: True Experimental design, factorial experiments, pyrometallurgy.

\section{Introduction}

Manganese material is a very important element that is used in a variety of industrial uses, for example, friction-resistant steel and batteries, [1]. Nearly $90 \%$ of manganese in the world is used for the iron and steel industry. Manganese is used in the production of mild steel, high carbon ferromanganese and silicomanganese. [2]. One area with promising manganese deposits is manganese from the island of Timor, East Nusa Tenggara province. Manganese layers related to sedimentary rocks have been found in the south of Central Timor Regency, Timor Island, Indonesia [3]. Even the possibility is not closed to neighboring Timor Leste. Manganese ( $\mathrm{Mn})$ is a free element and is widely shaped like oxides, silicates, carbonates which are the most common compounds.

Carbon steel is a steel with a minimum content of alloying elements, so carbon steel is often engineered to increase toughness. The usual technique is to increase hardness by means of hardening in the form of heat treatment. One of the hardening methods is pack carburizing. Carburizing is the addition of carbon to the surface of low carbon steel at temperatures in the austenitic region, which generally is between $800^{\circ} \mathrm{C}$ to $950^{\circ} \mathrm{C}$ for low carbon steel [4]. The carburizing process on low carbon steel can increase surface hardness so that it can withstand hardness and strength increases. The process of packaging carburization with workpieces and 
carbon is placed in a container to ensure optimal surface hardening. Previous studies using walnut shells as carbonisation material and [5], using cob powder and pearl house charcoal powder with carburizing can also increase the hardness of low carbon steel. In connection with the results of the aforementioned research, this study experimentally want to design manganese powder in certain particle sizes on carbon steel with a carburizing pack approach. More or less the same treatment is based on a new direct alloy process using manganese oxide composite pellets in the converter.[6] Steels with higher Mn content will be very sensitive to heating treatment and tend to have coarse grains. A characteristic of high $\mathrm{Mn}$ alloy steel is its fibrous structure. These fibers occur because $\mathrm{Mn}$ has a high reaction ability with various nonmetallic elements being $\mathrm{MnO}, \mathrm{MnS}, \mathrm{MnO} . \mathrm{SiO} 2$ and $(\mathrm{MnO}) 2 . \mathrm{SiO} 2$ [7]. There are several methods in the process of metallurgical manganese namely pyrometallurgy and hydrometallurgy [8]. Hydrometallurgy can be interpreted as a way of processing metals from rocks or ores by using aqueous solvents, or in detail, hydrometallurgy is a process in metallurgical work where the use of a liquid chemical is used to dissolve a particular particle. Pyrometallurgy is a metal extraction process with thermal energy, the general temperature used ranges from $500^{\circ} \mathrm{C}-1600^{\circ} \mathrm{C}$. At this temperature most metals are already in the liquid phase and sometimes even the gas phase [9]. Thus, the method used is the method of action for heat treatment in a heat treatment furnace and conduct morphological testing with SEM and chemical composition analysis (EDX). SEM is used to identify and characteristics that can provide higher resolution and provide assistance for researchers to be able to observe what is happening in and around the interface between the material and the oxide layer in detail [10].While the results of the hardness test were analyzed by factorial experimental methods. It is stated that the approach used a pack carburizing approach, which is a diffusion process using manganese and coal as a reduction media.

The design of heat treatment of manganese powder on carbon steel with the carburization packaging process is expected to produce a suitable low carbon steel directly proportional to the reduction and oxidation of manganese from the pyrometallurgy process. Good experimental results will be achieved if the experimental design is developed statistically precisely in accordance with the design chosen. [11] 


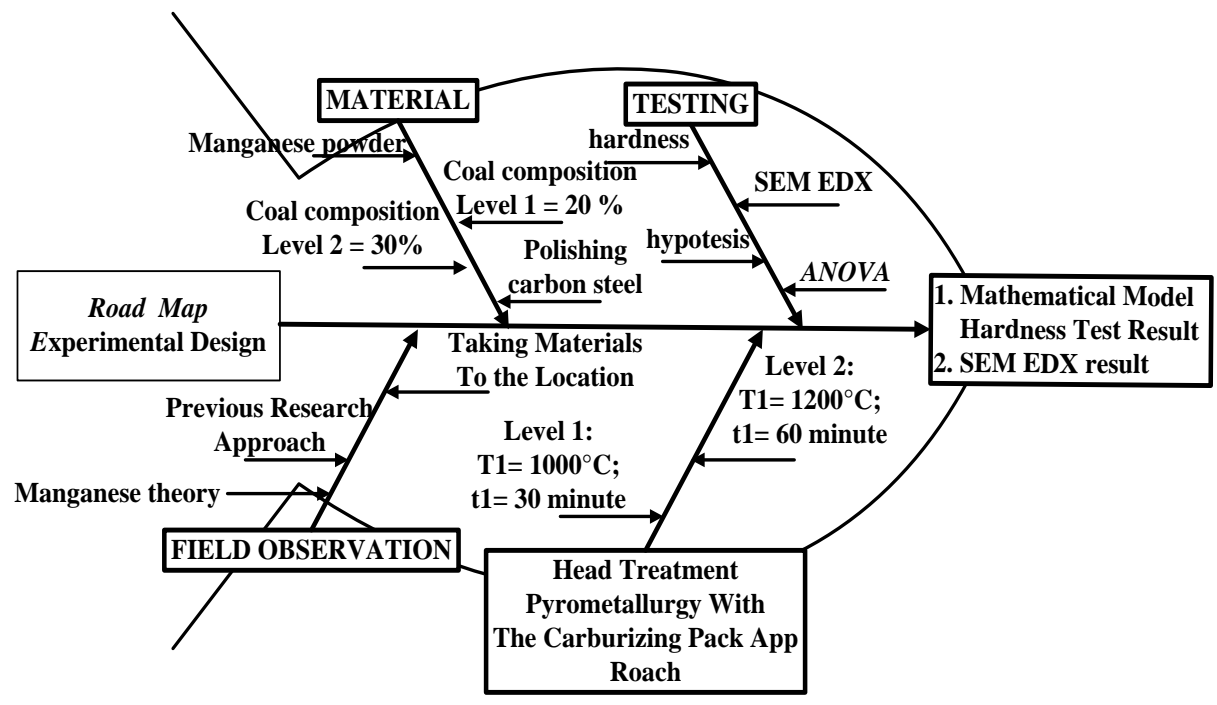

Figure 1. Research Road Map with Cause Effect Diagram

Generally, in a factorial experimental design, experimental trials (or runs) are performed at all combinations of factor levels [12]. In the factorial experiments, it can be seen the influence of individual factors and the influence of factor interactions. Talk about the significance of influence factors and their interactions, one of them uses the ANOVA method. Further explanation of the entire study explains the research journey from input to output with cause and effect diagram as in Figure 1.

\section{Method}

The research stages begins with ideas on how to add the chemical composition of metal alloys to the surface of carbon steel, such as manganese. The aim is to produce steel that is tough, hard and friction-resistant. Previous research using the full factorial experimental design was used to analyze the effects of factors and their interactions [13] can be applied to this study. The mineral stone used is manganese from the South Central Timor district as a concentrate of manganese mineral powder for diffusion media. The method chosen in this study is the reduction process at high temperatures using coal. The stages of the study are illustrated in the flow chart in Figure 2. The flow chart shows:

a. The experimental design method used a factorial experiment with 3 factors and 2 levels.

b. ANOVA testing uses one way ANOVA with a significance level $(\alpha)=5 \%$. If F.count <F.table, the null hypothesis is accepted and hypothesis one is rejected, and if Fcount> FTabel, the null hypothesis is rejected and accepts the first hypothesis. After ANOVA testing, a mathematical model will be determined in which this factorial experimental data processing uses Sigma Plott 12.5 software. 


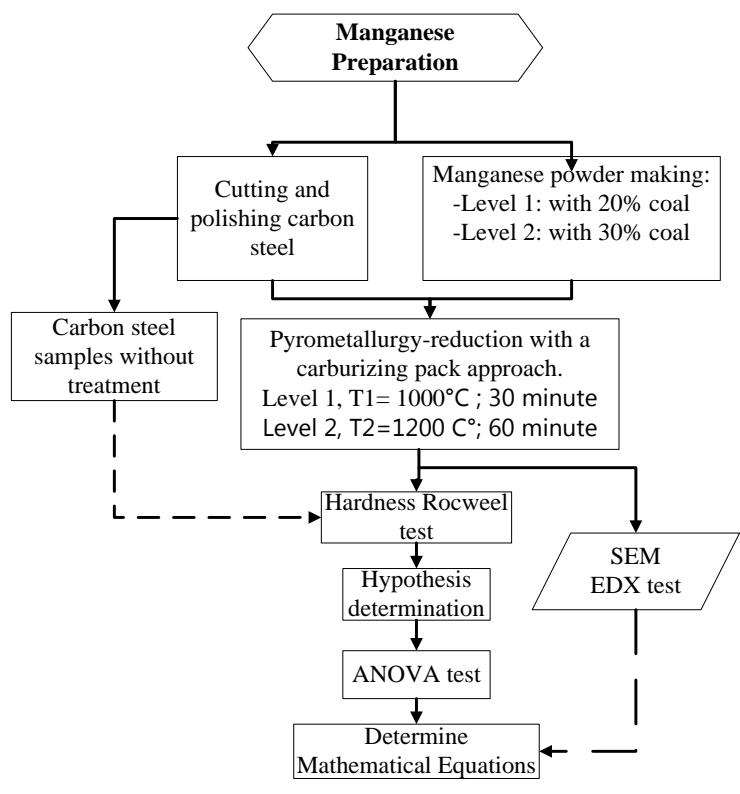

Figure 2. Research flow chart

\section{Discussion}

\subsection{Test Implementation}

The test is carried out in accordance with the research plan approved above, and the results can be seen in the following table:

Table 1. Results of Carbon Steel Hardness Tests That Have Got Treatment

\begin{tabular}{|l|l|l|c|c|c|c|}
\hline \multirow{2}{*}{$\begin{array}{l}\text { Reduction } \\
\text { (pyrometallurgy) }\end{array}$} & Coal composition & \multirow{2}{*}{ No } & \multicolumn{4}{|c|}{ hardness test (HRB) } \\
\cline { 4 - 7 } & & & \multicolumn{2}{|c|}{$1000^{\circ} \mathrm{C}$} & \multicolumn{2}{|c|}{$1200^{\circ} \mathrm{C}$} \\
\cline { 3 - 6 } & & 1 & 98.20 & 106.44 & 101.24 & 104.35 \\
& \multirow{4}{*}{$20 \%$} & 2 & 102.31 & 105.36 & 102.51 & 107.46 \\
& & 3 & 103.56 & 103.27 & 96.89 & 103.27 \\
& & 4 & 97.88 & 102.63 & 100.95 & 106.11 \\
& & 5 & 103.20 & 105.67 & 103.41 & 105.67 \\
\cline { 3 - 6 } & & 1 & 100.23 & 103.80 & 102.56 & 104.47 \\
& \multirow{3}{*}{$30 \%$} & 2 & 97.55 & 106.77 & 102.71 & 107.66 \\
& & 3 & 103.30 & 104.11 & 100.25 & 105.10 \\
& & 4 & 102.11 & 105.70 & 101.10 & 106.45 \\
& & 5 & 102.19 & 104.93 & 99.25 & 104.56 \\
\hline
\end{tabular}

\subsection{Hypothesis Determination}

1. H01: There is no significant difference between the temperature $(\mathrm{T})$ factors in influencing carbon steel hardness 
H11: There is a significant difference between the temperature $(\mathrm{T})$ ( factors in influencing the hardness of carbon steel.

2. H02: There is no significant difference between the holding time $(\mathrm{H})$ factors in influencing the low carbon steel hardness.

$\mathrm{H} 12$ : There is a significant difference between the holding time $(\mathrm{H})$ factors in influencing carbon steel hardness.

3. H03: There is no significant difference between coal reduction composition $(\mathrm{C})$ factors in influencing carbon steel hardness.

H13: There is a significant difference between the coal reduction composition (C) factors in influencing carbon steel hardness.

4. H04: There is no significant difference between the interaction of temperature factors and holding time $(\mathrm{TH})$ in influencing carbon steel hardness.

H14: There is a significant difference between the interaction of temperature factors and holding time $(\mathrm{TH})$ in influencing carbon steel hardness.

5. H05: There is no significant difference between the interaction of temperature factors and coal reduction composition (TC) factors in influencing carbon steel hardness.

H15: There is a significant difference between the interaction of temperature factors and coal reduction composition (TC) factors in influencing carbon steel hardness.

6. H06: There is no significant difference between the interaction of holding time factors and the composition ( $\mathrm{HC}$ ) of coal reduction in influencing the hardness of carbon steel. H16: There is a significant difference between holding time interactions and the composition (HC) factors in influencing the hardness of carbon steel.

7. H07: There is no significant difference between the interaction of temperature factors, holding time and coal reduction composition (THC) in influencing the hardness of carbon steel.

H17: There is a significant difference between the interaction of temperature, holding time and coal reduction (THC) in influencing the hardness of carbon steel.

\subsection{ANOVA Test}

Before testing the ANOVA normality tests are carried out on 40 experimental data. Data normality test results, the p-value of 0.2675 is greater than the significance level of 0.05 so that the data can be concluded as normally distributed. These data are performed ANOVA test on the value of low carbon steel hardness. ANOVA test results can be seen in Table 2. as follows:

Table 2. ANOVA Test

\begin{tabular}{|c|r|r|r|r|r|}
\hline $\begin{array}{c}\text { Source of } \\
\text { variation }\end{array}$ & df & \multicolumn{1}{l|}{ SS } & F calculate & F table \\
\hline T & 1 & 17.1613 & 17.1613 & 0.7954 & 4.10 \\
H & 1 & 143.4574 & 143.4574 & 36.7158 & 4.10 \\
C & 1 & 2.4929 & 2.4929 & 0.3273 & 4.10 \\
TH & 1 & 46.2183 & 46.2183 & 7.1477 & 4.10 \\
TC & 1 & 17.0469 & 17.0469 & 2.3566 & 4.10 \\
HC & 1 & 43.0076 & 43.0076 & 6.5654 & 4.10 \\
THC & 1 & 15.7492 & 15.7492 & 2.1669 & 4.10 \\
\hline Error & 38 & 289.9408 & 76300 & & \\
Total & 39 & 291.9324 & 7.4854 & & \\
\cline { 1 - 3 } & & \multicolumn{5}{|l}{}
\end{tabular}


Table 2. ANOVA test results show that holding time $(\mathrm{H})$, holding time $(\mathrm{H})$-composition of coal reduction $(\mathrm{C}), \mathrm{HC}$ and temperature $(\mathrm{T})$-holding time $(\mathrm{H})$-composition of coal reduction (C) or HC that affect hardness. These three factors are called influential because each F.calculate> F.table is strong enough to describe:

- $\quad$ Refuse H02 and accept H12 with F.calculate $>$ F.table $(36.7158>4.10)$

- $\quad$ Refuse H04 and accept H14 with F.calculate $>$ F.table $(7.1477>4.10)$

- $\quad$ Refuse H07 and receive H17 with F.calculate $>$ F.table $(6.5654>4.10)$

Next to calculate the mathematical model of this experiment is to analyze the regression of each factor against the hardness value. The results of the regression analysis are shown in the following calculation table:

Table 3. Regression Analysis

\begin{tabular}{|c|r|r|r|r|}
\cline { 2 - 5 } \multicolumn{1}{c|}{} & \multicolumn{1}{c|}{ Coef } & \multicolumn{1}{c|}{ SE. Coef } & \multicolumn{1}{l|}{ T } & \\
\hline Constan & 102.7332 & 0.0387 & & \\
T & 0.0567 & 0.0636 & 0.8918 & 0.3781 \\
$\mathrm{H}$ & 0.1641 & 0.0271 & 6.0594 & $\prec 0.0001$ \\
$\mathrm{C}$ & 0.0216 & 0.0378 & 0.5721 & 0.05706 \\
$\mathrm{TH}$ & 0.0931 & 0.0348 & 2.6375 & 0.011 \\
$\mathrm{TC}$ & 0.0566 & 0.0368 & 1.5351 & 0.133 \\
$\mathrm{HC}$ & 0.0898 & 0.0351 & 2.5623 & 0.0145 \\
$\mathrm{THC}$ & 0.0544 & 0.0369 & 1.4721 & 0.1492 \\
\hline
\end{tabular}

Based on table 3. of the regression analysis results above, the mathematical models obtained are:

$$
\mathrm{Y}=102.7332+0.1641 \mathrm{X} 1+0.0931 \mathrm{X} 2+0.0898 \mathrm{X} 3
$$

Where:

$\mathrm{X} 1$ = holding time

$\mathrm{X} 2$ = temperature - holding time

$\mathrm{X} 3$ = temperature - holding time - reduction composition

\subsection{Scanning Electron Microscope (SEM) Test with Energy Dispersive X-ray (EDX).}

This test is more to describe the surface characteristics, topography, and texture of the experimental results and elemental composition of the compounds contained in the experimental steel. In the pictures (a), (b) and (c) are SEM test results showing the texture and sample topography. The figure (a) is a comparison sample or original sample of low carbon steel that has been polished, visible in texture, smooth and even. In figure (b) is a low carbon steel level of $1200^{\circ} \mathrm{C} 60$ minutes and a coal composition of $20 \%$. showing a rougher texture and surface topography of steel samples appearing larger grains. It can be concluded that carbon steel samples in this condition are significantly affected by other elements. Figure (c) at the level of $1200^{\circ} \mathrm{C} 60$ minutes with $30 \%$ coal composition. The texture and topography of the steel surface are slightly smoother and more tenuous, showing the influence of other elements on the sample level is slightly lower 


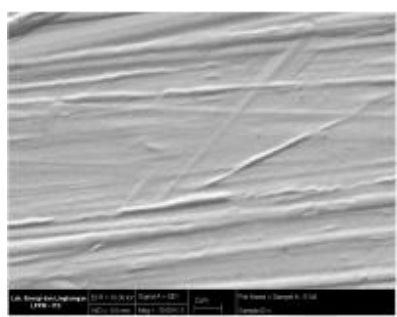

(a)

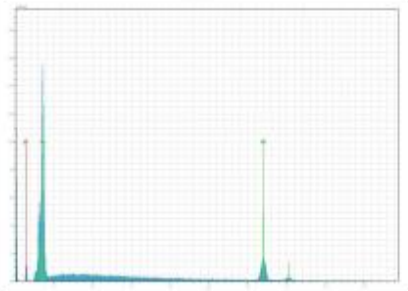

(d)

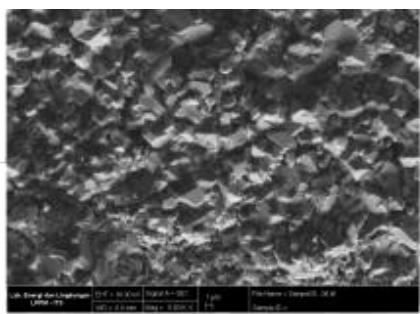

(b)

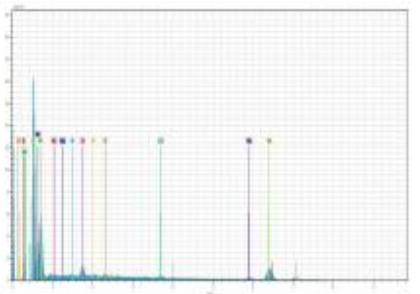

(e)

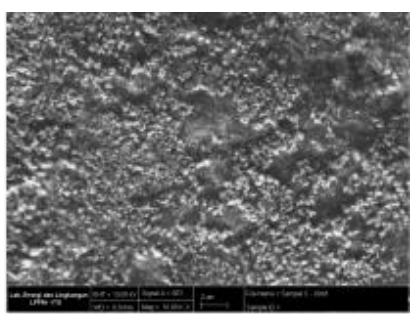

(c)

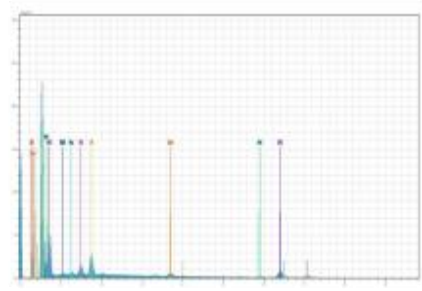

(f)

Figure 4. SEM test with surface topography (a, b, c) and graph of chemical composition with $\operatorname{EDX}(d, e, f)$

Figures (d), (e), and (f) explain the EDX graph with the detection of some chemical elements and their composition in each of the following samples:

- Figures $(a, d)$. Chemical composition of the surface of the original object, low carbon steel ST 37 without preparation, unsolved solution $98.7 \% \mathrm{Fe}$ and $1.53 \% \mathrm{C}$.

- $\quad$ Figures (b,e). Chemical composition of steel surface at $1100^{\circ} \mathrm{C} 20 \%$ coal in manganese powder, and holding time 60 minutes. Significant changes in chemical composition were seen on the steel surface, namely the formation of no Oxygen $(\mathrm{O}) 28.30 \%$, Manganese (Mn) 5.83\%, Silicon or Silicium (Si) 1.14\%, Calcium (Ca) $1.09 \%$, Sodium (Na) $0.7 \%$, Sulfur (S) $0.26 \%$, Phosphorus (P) and Almunium (Al) $0.02 \%$. Of all that, it was not formed from a mixture of manganese and coal powders consisting of several metals and non-metals. Expectations of the formation of manganese metal (Mn) which bind $\mathrm{Fe}$ (iron) are fulfilled insignificant levels and Carbon (C). The element Oxygen $(\mathrm{O})$ that is formed is very dominant due to the oxidation-pyrometallurgy reduction process. Oxygen compounds are formed by other binders, Silicon ( $\mathrm{Si}$ ) or Aluminum (Al). These compounds, although lightweight, usually float on steel surfaces that are hot or melting. While none other than non-sulfur $(\mathrm{S})$ and phosphorus $(\mathrm{P})$ are non-metallic metals which are always the default steel and contain less than $0.05 \%$.

- Figures (c,f). Chemical composition of steel surface at $1200^{\circ} \mathrm{C}$ and $30 \%$ coal in manganese powder, and holding time is 60 minutes. The same with Table 5., yields uncertain $\mathrm{O}, \mathrm{Mn}, \mathrm{Si}, \mathrm{Ca}, \mathrm{Al}, \mathrm{Mg}$, and $\mathrm{Na}$. Even though the expected percentage of the chemical composition of Manganese (Mn) is not as big as table 5. Surprisingly enough Silisium ( $\mathrm{Si}$ ) and the chemical composition of Oxygen $(\mathrm{O})$ and Carbon $(\mathrm{C})$ are formed larger. This is because, in the reduction process, the percentage of coal is greater than the previous experiment in table 5, by $20 \%$. Coal in its use uses a lot of carbon in the reduction process. It can determine that holding time, coal composition and temperature influence the formation of Fe-Mn composition. 


\section{Conclusion}

Based on the results of the experimental design of low carbon steel hardness that received pyrometallurgy treatment with pack carburizing approach, it can be concluded:

1. Data normality test results, the p-value of 0.2675 is greater than the significance level of 0.05 so that the data can be concluded as normally distributed.

2. Table 3. ANOVA test results show that holding time (T), holding time (T) -size (U) TU and temperature $(\mathrm{T})$-holding time $(\mathrm{W})$-size $(\mathrm{U})$ or TWU affect hardness. These three factors are called influential because each Fcount> $\mathrm{F}$ table is strong enough to describe: Refuse H02 and accept H12 with F.count $>$ F.Table $(36.7158>4.10)$

Refuse H04 and accept H14 with F.count $>$ F.Table $(7.1477>4.10)$

Refuse $\mathrm{H} 07$ and receive $\mathrm{H} 17$ with F.count $>$ F.Table $(6.5654>4.10)$

3. Based on table 4. of the regression analysis results above, the mathematical models obtained are:

$\mathrm{Y}=102.7332+0.1641 \mathrm{X} 1+0.09931 \mathrm{X} 2+0.0898 \mathrm{X} 3$

Where:

$\mathrm{X} 1$ = holding time

$\mathrm{X} 2$ = temperature - holding time

$\mathrm{X} 3$ = temperature - holding time - reduction composition

4. SEM EDX test results show the formation of elements of Manganese (Mn) and several other elements on the steel surface from the oxidation and pyrometallurgical reduction process at a temperature of $1200^{\circ} \mathrm{C}$.

\section{References}

[1] A. Wibawa, "TRANSFORMASI MINERAL PIROLUSIT PADA TEMPERATUR TINGGI Transformation of Pirolusite Mineral at High Temperature," vol. 14, no. September, pp. 179-186, 2018.

[2] S. Sumardi, M. Z. Mubarok, and N. Saleh, "Pengolahan Bijih Mangan Menjadi Mangan Sulfat Melalui Pelindian Reduktif Menggunakan Asam Oksalat Dalam Suasana Asam," pp. 123-130, 2013.

[3] A. Idrus, E. M. Ati, A. Harijoko, F. M. Meyer, and J. Grafika, "Characteristics and Origin of Sedimentary-Related Manganese Layers in Timor Island, Indonesia Sedimen di Pulau Timor , Indonesia," vol. 8, no. 4, pp. 191-203, 2013.

[4] W. S. J. dan S. V. Mirantie Dwiharsanti, "PERANCANGAN EKSPERIMEN BAJA KARBON RENDAH HASIL PROSES PACK CARBURIZING DENGAN METODE EKSPERIMEN DESIGN OF EXPERIMENT OF LOW CARBON STEEL RESULTED FROM PACK," pp. 92-97.

[5] Sujita, "Proses P ack Carburizing dengan Media Carburizer Alternatif Serbuk Arang Tongkol Jagung dan Serbuk Cangkang Kerang Mutiara," J. Mech., vol. 7, no. 2, pp. 36-41, 2016.

[6] B. Zhang and Z.-L. Xue, "Kinetics Analyzing of Direction Reduction on Manganese Ore Pellets Containing Carbon," Int. J. Nonferrous Metall., vol. 02, no. 03, pp. 116$120,2013$.

[7] R. Binudi and B. Adjiantoro, "PENGARUH UNSUR Ni, Cr DAN Mn TERHADAP SIFAT MEKANIK BAJA KEKUATAN TINGGI BERBASIS LATERIT,” Metalurgi, 
vol. 29.1.2014, pp. 33-40, 2014.

[8] S. Tarumingkeng, E. J. Mustopa, and L. Hendrajaya, "TERMODINAMIKA DALAM MEMAHAMI PROSES PENGOLAHAN MINERAL," vol. V, pp. 37-42, 2016.

[9] A. Wibawa, "PENGARUH TEMPERATUR TERHADAP REDUKSI BIJH MANGAN,” pp. 221-228, 2014.

[10] A. Sujatno, R. Salam, A. Dimyati, P. Sains, and B. Maju, "STUDI SCANNING ELECTRON MICROSCOPY ( SEM ) UNTUK KARAKTERISASI PROSES OXIDASI PADUAN ZIRKONIUM,” vol. 9, no. November, pp. 44-50, 2015.

[11] Enny Supartini, "Menentukan Statistik Pengujian Untuk Eksperimen Faktorial dengan Dua Kali Pembatasan Pengacakan," PROSIDING, pp. 978-979, 2009.

[12] G. C. R. Douglas C. Montgomery, D. C. Montgomery, G. C. Runger, and G. C. R. Douglas C. Montgomery, "Design of Experiments with Several Factors," in Applied Statistics and Probability for Engineers, John Wiley \& Sons, 2011, pp. 505-570.

[13] M. Askari-Paykani, M. Shayan, and M. Shamanian, "Weldability of ferritic ductile cast iron using full factorial design of experiment," J. Iron Steel Res. Int., 2014. 